\title{
Hans Chr.Iversen
}

En sønderjysk lærer og hans erindringer fra Tønder

Seminariums danske afdeling 1869-72

\section{Af Peter Kr.Iversen}

Tønder Statsseminarium fejrer $\mathrm{i}$ år sin 200-års fødselsdag. I de første 20 år efter 1864 var seminariet delt $i$ to afdelinger, en A-afdeling, som var tysksproget, og en B-afdeling, som var dansksproget. Den aldste kendte beretning om livet på den danske afdeling omfatter årene 1869-72 og er skrevet af Hans Chr.Iversen. Han var lærer i Sønder Sejerslev fra 1884 til 1908 . Iversen var et barn af grænselandet, draget både af det danske og det tyske. Hans erindringer om seminarieårene udgives her $i$ anledning af seminariets jubilæum.

\section{Indledning}

Tønder Statsseminarium, Nordens aldste læreruddannelsesskole, kan Mikkelsdag den 24.september 1988 fejre sit 200-års jubilæum. Vel næppe noget andet seminarium har $\mathrm{i}$ årenes løb været gjort til genstand for så megen omtale som dette - og det både fra dansk og tysk side. Bl.a. foreligger der gode skildringer om forholdene på den danske afdeling i det korte åremål, den eksisterede under det tyske fremmedherredømme. Senere degn og lærer $i$ Asserballe Matthias Matthiesen, klassekammerat til bl.a. redaktørerne Mathies C.Mathiesen, Haderslev og Jens Jessen, Flensborg, har skrevet om årene 1872-74, den senere så kendte kreditforeningsdirektør og politiker J.H.Schmidt, Vojens om tiden 1875-78, medens senere viceskoleinspektør i København Niels Peter Olsen har berettet om årene 1881-84. Utrykt er senere lærer i Skærbæk Jens Andersen Jensens erindringer fra årene på afdelingen 1872-75, og den ældst kendte af beretningerne stammer fra senere degn og lærer i Sønder Sejerslev Hans Chr. Iversen. Han var elev på seminariet 1869-72 og var i øvrigt svoger til Niels Peter Olsen'.

\section{Levnedsskildring af Hans Chr.Iversen}

Hans Christian Iversen var født den 14.marts 1850 i Abild, hvor hans fader Jens Iversen ${ }^{2}$ var degn og lærer i årene 1845-58. Faderen, der havde fået sin uddannelse ved Skårup seminarium, hvorfra han dimitteredes 1838, var almindelig anerkendt som en dygtig pædagog og respekteret såvel i danske 


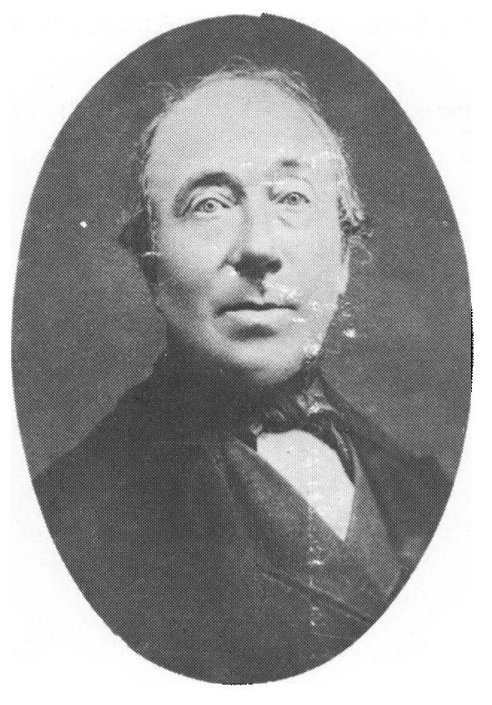

Degn og lerer i Bredebro Jens Iversen, 1817-82, Hans Chr. Iversens fader. Han oprettede 1861 et praparandkursus og var 1874 stifter af den forste larersammenslutning $i$ den nordlige del af Tonder amt. Foto Chr. Schwennesen, Tonder. Historiske Samlinger.

som i tyske kredse. Efter at han i 1858 havde fået overdraget det bedre aflagte embede som degn og lærer i Bredebro, oprettede han dér 1861 et præparandkursus for vordende seminarister, som fra 1864 kom under tilsyn af Tønder seminariums forstander eller direktør, som den noget fornemmere titel egentlig var. Mange af landsdelens dansksindede lærere fra fremmedherredømmets tid fik her deres første lærdom og fik samtidig i underskolen prøvet deres evner som pædagoger, hvilket ikke just altid faldt heldigt ud for disse halvvoksne knøse. Jens Iversen var 1874 initiativtager til oprettelse af lærerforeningen for de dansktalende distrikter i Tønder og Løgumkloster provstier. Blandt foreningens stiftende medlemmer var også sønnen Hans Chr.Iversen, på den tid lærer i Rabsted.

Hans Chr.Iversen ${ }^{3}$ fik en god opdragelse i det stærkt religiøst prægede hjem, hvor der blev sunget meget. Med glæde mindes han i sine erindringer barndomsårene i Abild, hvor han sammen med en søster var daglig gæst i præstegården. Pastor Jessen ${ }^{4}$ og hans familie var tysksindet, men kom godt ud af det med den dansksindede degnefamilie. Også i Bredebro fik Hans Chr.Iversen en god legekammerat med den jævnaldrende præstesøn Broder Ratenburg 5 . Han fik en god undervisning hos faderen, men bebrejder sig selv i sine erindringer for manglende flid. Han har sikkert fortsat undervisningen hjemme sammen med præparanderne hos faderen og blev derefter først hjælpelærer i Bylderup 1866-67 hos degn Anders Nissen ${ }^{6}$, senere underlærer 1867-69 hos faderen i Bredebro, hvor han fortsatte med at forberede sig til optagelses- 
prøven på seminariet i Tønder. I første omgang 1868 klarede han ikke prøven, men året efter bestod han.

Efter veloverstået eksamen 1872 fik han først stilling som lærer i Nordborg, hvor den tidligere præst i Abild Georg Friedrich Jessen nu havde embede og var skoleinspektør. Her kom han fortrinsvis til at undervise i mellemklassen, men havde dog også to timer i første, d.v.s. øverste drengeklasse. Endvidere måtte han hver søndag gøre tjeneste i kirken som kantor og nu og da også spille orgel, når ungdomsvennen, degn og organist Johan Hinrich Sell ${ }^{7}$, der var en lidet dygtig organist, meldte forfald. Han havde forholdsvis lidt at bestille som lærer, nød de smukke naturomgivelser og spillede og sang sammen med nogle venner. Årslønnen på 750 mark var ikke tilstrækkelig til, at han kunne deltage i det nordborgske selskabsliv, men han var dog "for en forms skyld « medlem af både den tyske forening Harmonie og den danske Concordia og tog enkelte gange del i de baller, som foreningerne arrangerede om vinteren. Han fik også tid til yderligere at dygtiggøre sig. På egen hånd læste han ivrigt engelsk og botanik og havde egentlig $i$ sinde at tage eksamen som mellemskolelærer, men beklagende meddeler han i sine erindringer, at dette gode forsæt gik i vasken. Sin værnepligt aftjente han sommeren 1872 i seks uger ved det 84 . infanteriregiment i Flensborg, hvor han »blev upåklageligt« behandlet af befalingsmændene.

Da pastor Jessen var blevet forflyttet og forfremmet til provst i Als Sønderherred, og førstelærer Sell ligeledes søgte bort og blev degn og organist $i$ Augustenborg, fandt Iversen også anledning til at søge bort, en beslutning, som han dog på sine gamle dage beklager. Det var andenlærerembedet $\mathrm{i}$ Rabsted, der fristede, ikke blot med en noget højere løn, men med en større bekendtskabskreds. Her i sognet havde hans fader 1839-45 været en afholdt lærer i Korup og hans onkel Christen Christensen ${ }^{8}$, der havde været gift med hans to fastre, havde her i mange år fra 1832-70 været degn og lærer. Onklen hørte til de udpræget dansksindede og var 1854 for sin trofaste indsats for danskheden blevet tildelt dannebrogsmændenes hæderstegn. Iversen blev en afholdt lærer i Rabsted, og hans pædagogiske evner blev gentagne gange rosende omtalt i aviserne. Dette sidste blev ikke uden betydning for ham, idet omtalen blev læst af hans velhavende farbroder, gårdejer og kniplingskræmmer Andreas Iversen i Løgumgårde, som af glæde over de rosende ord forærede ham 300 mark til et klaver, og det var på den tid en ganske betydelig sum.

Men der var også andre, der var blevet kendt med hans arbejde. Han fik opfordring til at søge lærerstillingen i Solderup, Hostrup sogn, hvor han kunne få en årlig løn på 1200 mark, en stor løn for en ung ugift lærer. Han var herefter enelærer i Solderup fra 1877-84, og hans søster Marie ${ }^{10}$ flyttede foreløbig med som hans husbestyrerinde i den nyrestaurerede lærerbolig. Til 
embedet hørte et lille landbrug, hvor der kunne holdes to køer. Også her faldt han godt til og øgede sine indtægter ved at give musikundervisning til forskellige velhavende gårdmænds døtre. Da han imidlertid 1883 havde forlovet sig med Ingeborg Helene Holt ${ }^{11}$ fra en udpræget dansksindet gårdmandsfamilie i Åspe, Brede sogn og gerne ville giftes, slog embedets indtægter ikke til. Han begyndte derfor at se sig om efter en anden og mere givtig stilling, og han var nu så gammel i tjeneste, at han kunne komme i betragtning som degn og førstelærer. Fra 6.april 1884 betjente han derefter stillingen som degn og organist i Emmerlev sogn og førstelærer i Sønder Sejerslev.

\section{Det danske lærerhjem i Sønder Sejerslev}

Iversen var en dygtig organist, og det lykkedes ham snart at få det »ikke just videre berømte« orgel grundigt repareret, så at det »nu blev ulastelig, endogså ret behagelig at spille påর. Den lokale skoleforstander Christian Hansen Lausten ${ }^{12}$ i Sønder Sejerslev havde forinden indflytningen sørget for at få den gamle, lavloftede og fugtige skole nødtørftigt restaureret, og her udfoldede der sig efter brylluppet den 28.april 1884 med en voksende børneflok et lykkeligt familieliv. Degneboligen var imidlertid trods hovedreparationen langtfra god og blev årsag til megen sygdom både blandt voksne og børn. Iversen arbejdede derfor bl.a. under stor modstand fra den magtfulde skolepatron, amtsforstander og senere rigsdagsmand Theodor Feddersen ${ }^{13}$, ejer af Søndergårde og Kogsbøl Ladegård, på at få en ny skole- og degnebolig opført, men først 1903 stod den nye skole færdig. En alvorlig skærmydsel havde han endvidere med sin ærkefjende, amtsforstanderen $i$ anledning af noget juletræspynt. Fra julen 1886 havde Iversen nemlig indført den gode skik at holde juletræsfest $\mathrm{i}$ skolen, en begivenhed der fandt sted årligt indtil 1901. Men da amtsforstanderne den 5.december $1902^{14}$ havde fundet anledning til at skrive en skarp advarsel til Iversen, fordi det var rygtedes, at juletræet bl.a. blev pyntet med røde og hvide papirsroser, måtte skikken til beklagelse for børn og forældre opgives, da Iversen ikke ønskede amtsforstanderens indblanding $i$, hvorledes skolens juletræ skulle pyntes.

Det har uden tvivl været en vanskelig balancegang for ham som så mange andre sønderjyske lærerkolleger at begå sig over for de tyske skolemyndigheder. Hjemmet var rent dansktalende, ja hustruen Ingeborg Helene kunne næppe formulere en sætning på tysk, og hele hans omgangskreds i Emmerlev sogn, når bortses fra præsten, var dansk. Han deltog i sognebørnenes glæder og sorger. Til bryllupper, sølv- og guldbryllupper skrev han sange ${ }^{15}$, som regel med et stærkt kristeligt præg. Som noget, der siges ikke at være helt almindeligt 


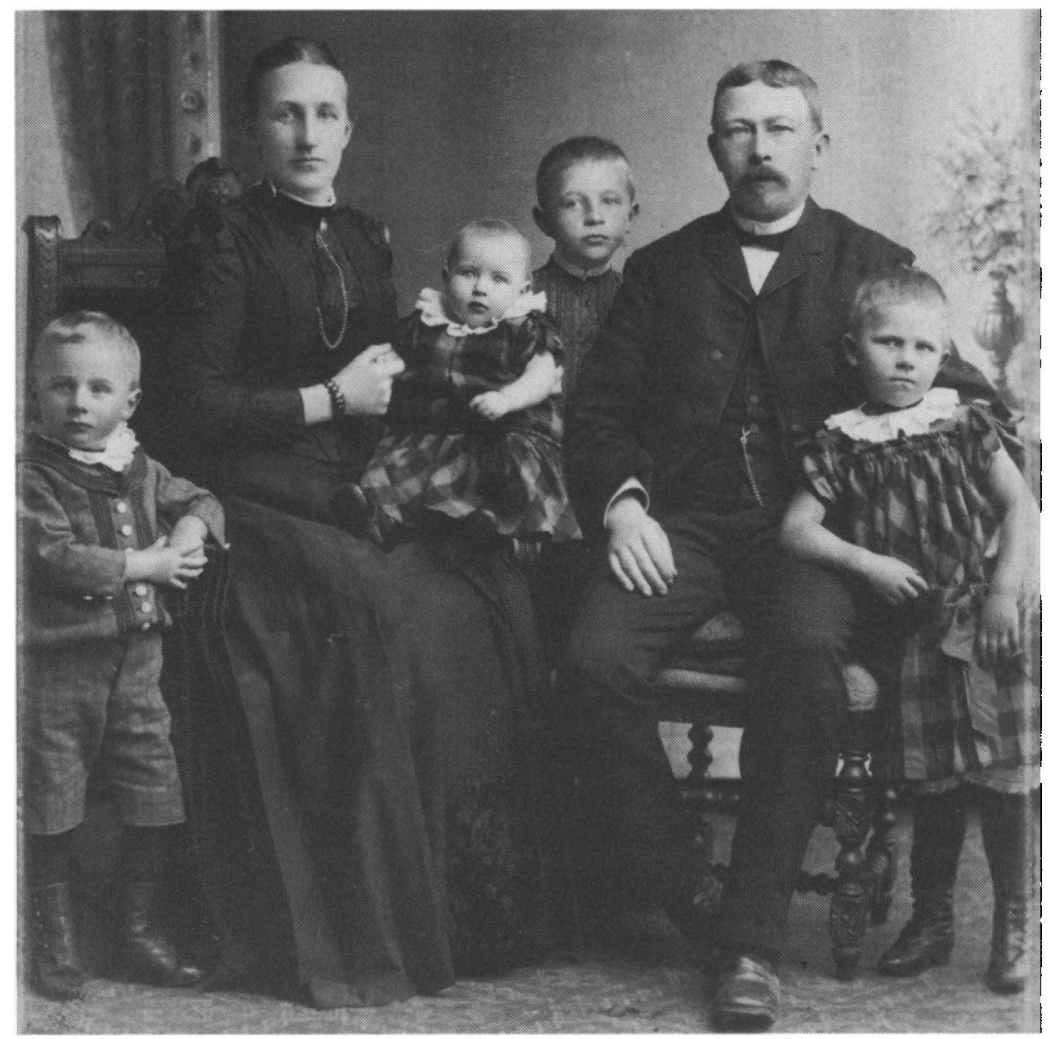

Degnefamilien Iversen, foto 1890. Fra venstre Lorenz, senere tandlage $i$ Tonder, hustruen Ingeborg Helene, f. Holt, Margrethe, senere gift med gårdejer og dannebrogsmand Peter I. Iversen, Bonderby, Jens, senere rektor i Hamborg, Hans Chr. Iversen, Hanne, senere gift med gärdejer Adolf Sarensen, Vester Gammelby. Foto Chr. Schwennesen, Tonder. Historiske Samlinger.

og næppe kendes fra andre dele af landet, forfattede han også danskskrevne sange eller salmer ved dødsfald og begravelser i og uden for familien. $\mathrm{Nu}$ og da har de vel været skrevet på bestilling, og han har, selv om det ikke var nødvendigt for ham $i$ et efter forholdene vel aflagt embede, måske kunnet tjene en ekstra skilling herved. Hans lille poetiske åre gav sig også udslag $\mathrm{i}$ digte og sange af mere alment indhold. Inden for familiens og venners kreds blev julesangen: „Alt stråler juletræet nu i sin fulde glans« sunget på melodien til »Nu titte til hinanden«. Sangen er trykt i Sønderjysk Månedsskrift 1958. Oprindelig var sangen tænkt sunget på melodien til den svenske nationalsang: "Du gamle, du fria...» Det har jo nok været lidt mærkeligt at gå rundt omkring juletræet til denne melodi, og måske kan en af årsagerne til amtsforstanderens 
vrede være afsyngelsen af sangen på denne melodi. Et andet digt: "Evighedstanker«, der vist også har været trykt, vidner om hans dybt religiøse indstilling.

Hans virke som lærer i Sønder Sejerslev og degn i Emmerlev sogn adskiller sig således ikke stort fra andre lærere, der var uddannet på Tønder seminariums danske afdeling, og som måtte klare den vanskelige balancegang over for de preussiske myndigheder. De nærmest foresatte, lokalskoleinspektøren, d.v.s. sognepræsten og kredsskoleinspektøren ${ }^{1 \text { sa }}$ kunne Iversen $i$ almindelighed så nogenlunde klare sig overfor, så meget desto mere, som den førstnæunte var temmelig fordrukken ${ }^{16}$ og lidet respekteret i menigheden. Efter kredsskoleinspektørens anvisning havde Iversen udarbejdet en skoleplan, som han kunne leve med, og da generalsuperintendent Kaftan den 13.september 1887 havde visiteret skolen, noterede han i sin dagbog: "Jeg høstede megen ros både for orgelspil og børnenes sang $\mathrm{i}$ kirken og mine børns præstationer $\mathrm{i}$ skolen «. Også ved hans afsked 1908 omtales hans gode færdighed som organist $^{17}$. Han var i det hele taget musikalsk anlagt. Mange af egnens gårdmandsdøtre har fået klaverundervisning hos ham, og som sanglærer dirigerede han

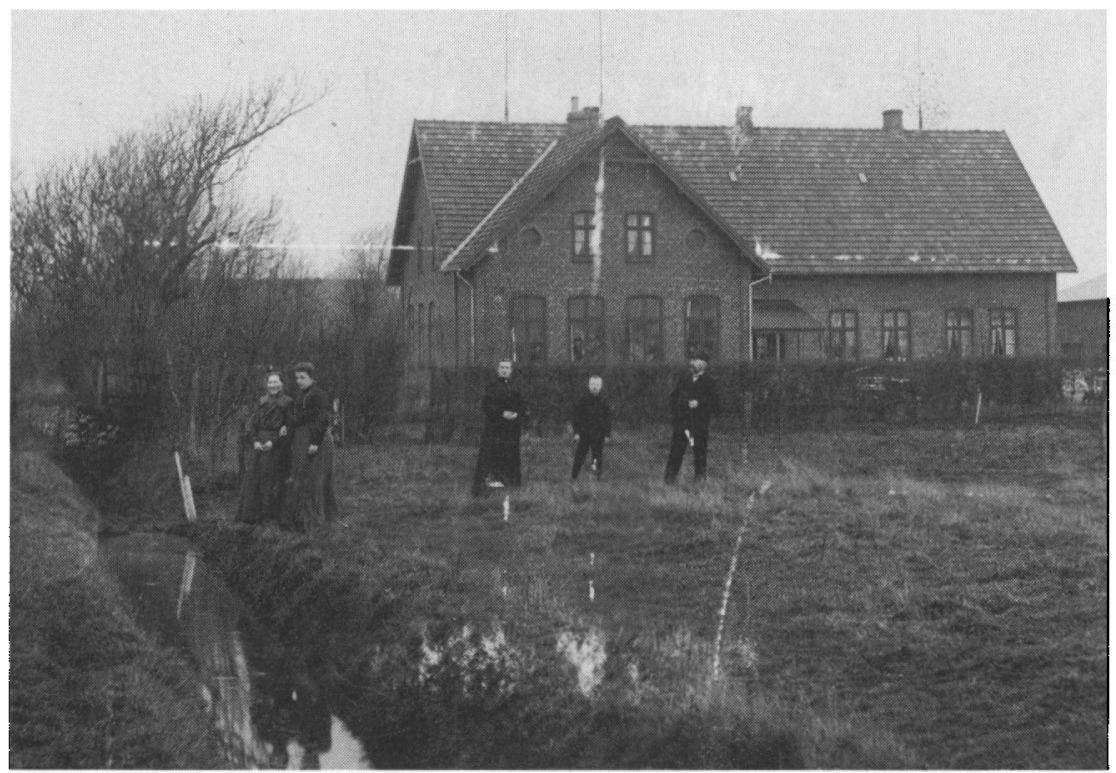

Skolen $i$ Sdr. Sejerslev, opfort 1903. Personerne fra venstre datteren Margrethe, Larerinde Magdalene Gregersen Wiuf, hustruen Ingeborg Helene, sannen Andreas, der faldt i 1. verdenskrig og Hans Chr. Iversen med sin uundvarlige lange pibe, som ogsa holdtes tandt $i$ alle skoletimerne. Foto ca. $1905 \mathrm{~A}$. Juul, Flensborg. Historiske Samlinger. 
fra 1896 Højer sangforening. Selv komponerede han en del melodier, bl.a. en melodi til: "Længe nok har jeg bondepige været«, en melodi, som i hvert fald endnu i 1920'erne blev benyttet i de vestslesvigske sogne.

Iversen ville vel næppe have kastet sin kærlighed på denne sang, hvis ikke hans danske herkomst og indleven i dansk kultur havde været af betydning for ham, og det kan i denne forbindelse nævnes, at $i$ hans bogskab stod danske digteres og forfatteres hovedværker i smukt indbundne rækker.

Han må, når bortses fra kontroverserne med amtsforstanderen og en proces angående degnelønnen, som han 1904 førte frem til overlandsretten i Kiel ${ }^{18}$ og vandt, siges at være kommet godt ud af det med den stedlige befolkning. Familien havde som nævnt en stor vennekreds blandt den helt overvejende danske befolkning og deltog i dens møder og arrangementer, så vidt stillingen som tysk lærer tillod det. Ved stiftelsen af Emmerlev sogns ringriderforening 1892 blev han foreningens forste sekretær ${ }^{19}$. Hans ældste datter blev 1907 gift med en af sognets ansete, danske landmænd.

\section{"Zweiströmigkeit«}

Men alligevel blev han i national henseende en splittet natur, udpræget »zweiströmig og man kan ikke undlade at tænke på hans svoger, viceskoleinspektør N.P.Olsens bemærkninger om de lærere, der udgik fra dansksindede hjem, og som for at undgå at blive sendt til Sydslesvig eller Holsten senere svigtede. Ordene kan måske netop være møntet på Iversen. Olsen skriver i sine erindringer: »Det er forståeligt, at mange $\mathrm{i}$ tidens løb faldt fra og - muligt på skrømt - gik over $i$ fjendens lejr, og der skal ikke gås for skarpt i rette med dem; ... «19a. Måske er det navnlig hensynet til børnenes, naturligvis specielt sønnernes fremtid, der har fået Iversen til at stå så usikker i national henseende, som tilfældet blev. Og denne usikkerhed satte ind på et tidspunkt, hvor danskheden stod svagest i Nordslesvig, og hvor han har næret ængstelse for at blive forflyttet sydpå, hvilket især for hans hustru måtte være særdeles ubehageligt. Dette kan måske ses som en slags undskyldning. Om hans "Zweiströmigkeit« mærkedes af hans nærmeste omgivelser $\mathrm{i}$ det daglige får stå hen, men $\mathrm{i}$ hans håndskrevne sange og lejlighedsdigte kan man finde et mindedigt $\mathrm{i}$ anledning af kejser Friedrich III's død 15.juni 1888 og endvidere et digt til kejserindens ære, endda skrevet til egen melodi. Også et digt om hertug Friedrich VIII ved hans ældstfødtes vugge kan nævnes. Disse sange kan måske have været brugt ved sammenkomster i lærerforeningen.

Den bærende idé for Iversen har været kærligheden til hjemstavnen og en dyb religiøs forankring, hvilket sidste især kommer til udtryk i hans lejligheds- 
digtning. Der kan dog næppe være tvivl om, at han trods de nævnte hyldestdigte omkring århundredskiftet ikke har været særlig velset af de preussiske myndigheder, som ønskede lærernes absolutte aktive medvirken i germaniseringsprocessen. Som nævnt havde han i overensstemmelse med kredsskoleinspektørens instruks udarbejdet en skoleplan, som givetvis i så vid udstrækning som muligt har tilgodeset den lokale befolknings interesser (jfr. juletræspyntningen), men skoleplanen har ikke været tilfredsstillende for den af de nordslesvigske lærere så forhadte geheimeråd Sass ${ }^{20}$ fra regeringen i Slesvig. Under en inspektion i Sønder Sejerslev skole den 8.juni 1908 kom det til et voldsomt verbalt sammenstød mellem de to. Sass kritiserede planen, som Iversen forsvarede under henvisning til, at den var udarbejdet $i$ overensstemmelse med kredsskoleinspektørens instruks. Han ville ikke finde sig i Sass' kritik og erklærede, at han herefter ikke kunne fortsætte som lærer, men ville søge sin afsked. Sass forsøgte ganske vist at glatte ud med en undskyldning, men Iversen ville ikke acceptere den. Han holdt fast ved sin beslutning om at ville søge sin afsked, og han skriver i sine optegnelser, at han ikke fulgte sin høje foresatte til dørs. Det har jo ikke været en helt almindelig inspektion for den gode geheimeråd, der ellers var vant til, at der blev bukket og skrabet for ham. Man kan jo også stille det spørgsmål, om episoden for Iversens vedkommende måske blot har været en kærkommen anledning til at komme ud af det preussiske skolevæsens spændetrøje?

Men hvorom alting er, han fik bevilget sin afsked pr. 1.oktober 1908, og begrundelsen for den 58 -årige lærers pensionering var svagelighed. Pensionen som lærer og degn blev fastsat til 2158 mark årligt, en efter den tids forhold ganske anselig sum. Hertil kom, at han takket være en arv efter den tidligere omtalte velhavende farbror var en relativt velsitueret mand, som ved siden af sin lærervirksomhed havde drevet et mindre landbrug med fire køer og en hest. Landbruget havde han dog måttet opgive 1903, da en ny skole og degnebolig langt om længe var blevet opført. Han havde da måttet sælge jord og besætning og havde fået penge på rente til supplering af lønnen. Han havde således uden de store økonomiske kvaler kunnet betale sine tre sønners skolegang og studier.

Efter afskeden flyttede Iversen til Møgeltønder, hvor han købte et hus på Møllevej. Når han søgte hertil, var en af årsagerne sikkert, at der her i forvejen boede to førtidspensionerede lærere, som også havde haft vanskeligt ved at omgås de preussiske skolemyndigheder, nemlig Jørgen Hansen Jensen ${ }^{21}$, tidligere førstelærer ved Toghale skole og Peder Jepsen ${ }^{22}$, sidst lærer i Bovrup. Endvidere var der $\mathrm{i}$ sognet to førstelærere, hvoraf Peter Eskildsen Jensen ${ }^{23}$, Møgeltønder skole var udpræget dansk, medens Alfred Petersen ${ }^{24}$ ved Toghale skole i hvert fald blev betragtet som moderat dansk, og det samme var tilfældet 
med andenlæreren ved Møgeltønder skole, Mads Jensen Bergmann ${ }^{25}$, senere førstelærer og degn i Kamptrup, Hygum sogn. Iversen kunne altså her hos kolleger finde en passende omgangskreds, og hvad der måske ikke var helt uvæsentligt, han fik også mulighed for fortsat at give undervisning i klaverspil. Helt uden betydning for valget af den nye bopæl har det næppe heller været, at der herfra var god jernbaneforbindelse til Tønder, hvor den yngste søn kunne reflektere realskolen. Men også hensynet til hustruen, der her fandt en passende omgangskreds, har sikkert spillet ind.

\section{Tyskheden drager}

Selv om han kom til et endnu mere end Emmerlev danskpræget sogn, og selv om han nu i tjenstlig henseende helt var befriet for hensyntagen til de preussiske myndigheder, er det på sin vis ikke let at forklare, hvorfor han nu mere og mere lod sig besnære af tyskheden. Hans forældre havde været danske, tre af hans søstre var med deres ægtefæller flyttet til kongeriget, hans ægtefælle var af en udpræget dansk familie og hans to døtre blev gift med danske

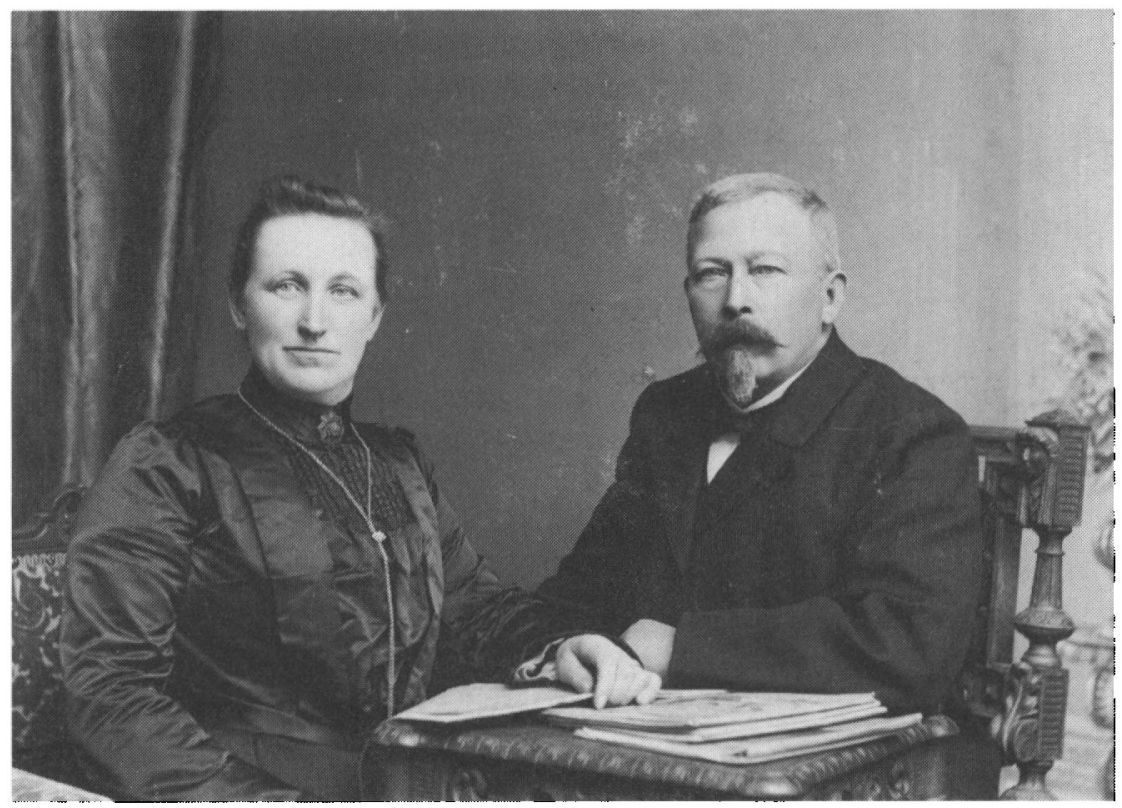

Hans Chr. Iversen og Ingeborg Helene, f. Holt, ca. 1910. Foto Chr. Schwennesen, Tonder. Historiske Samlinger. 
gårdmænd, hvoraf den ene i hvert fald var lokal dansk tillidsmand. En rimelig forklaring kan næppe gives, men det er blevet sagt - og helt urigtigt er det vel næppe -, at hensynet til hans tre sønners karriere i en landsdel, som fortsat måtte forventes at være inkorporeret i Tyskland, har spillet afgørende ind. Omvendt har i hvert fald de to ældste, tysksindede som de blev under deres studier, nok været med til at påvirke ham. Underlig splittet må han have været. Da så pastor Johs. Schmidt, Vodder, søn af hans gamle seminarieforstander, startede sin fredsforening, svigtede han for alvor sin slægts nationale tradition. Han evnede ikke eller ønskede i hvert fald ikke at gennemskue den Schmidt'ske dobbeltbundethed. Han lod sig lokke af foreningens program, som bl.a. skulle gå ud på at beskytte den nordslesvigske befolknings ejendommeligheder, fremfor alt holde modersmålet $\mathrm{i} æ$ ære, det tyske som det danske. Endvidere hed det i programmet, at al aktivitet på det politiske område skulle være udelukket fra foreningens virksomhed - skønne lokketoner, som blot på sin vis skulle bidrage til landsdelens fortyskning ${ }^{26}$. Iversen blev sammen med lærerne Alfred Petersen og Bergmann, Møgeltønder aktive medlemmer af foreningen, og sammen med disse to og rådmand Petersen ${ }^{27}$ fra Tønder deltog han den 12.februar 1912 som delegeret $i$ fredsforeningens møde, om formiddagen $i$ Flensborg og om eftermiddagen i Tinglev. Endvidere deltog han den 7.marts 1912 i et af pastor Schmidt $i$ Tønder afholdt "fredsmøde«. Dagbogsnotatet om dette sidste møde har Iversen mærkværdigvis nok skrevet på dansk, medens han ellers $i$ almindelighed på denne tid skriver oplysninger om familiebegivenheder på tysk.

Da 1. verdenskrig så brød ud den 1.august 1914, i øvrigt lige efter, at han, hans hustru og yngste søn havde været på en længere rundrejse i Jylland for bl.a. at besøge den talrige der bosatte familie, ængstedes han jo nok efterhånden for sønnernes skæbne, men var til at begynde med også stolt over de tyske hæres fremmarch og sønnernes andel deri. I nogle digte, som offentliggiordes i Tondernsche Zeitung og Nordischer Kurier, hyldede han soldaterne og ikke nok med det: Kejseren hyldes 1915 ikke blot med et digt, men også med egen melodi dertil, en march, hvortil noderne dog ikke ses at være bevaret. Også i breve $^{28}$ til svogeren N.P.Olsen og søsteren i København gav han udtryk for overbevisningen om retfærdigheden $i$ tysk sejr. England var, som han skriver den 23. december 1914, også forhadt i den dansksindede befolkning, og Rusland var barbarisk. Efterhånden som krigen skred frem, blev tonen dog noget mere afdæmpet, og ængstelsen for sønnerne og en svigersøn blev mere og mere fremherskende. Rent psykisk har angsten givetvis virket nedbrydende på ham helbredsmæssigt, og måske har han på det sidste som så mange andre mærket, i hvilken retning udviklingen gik. Han har nok taget sin egen vurdering af krigen og dens berettigelse op til fornyet overvejelse. Hvem ved? 


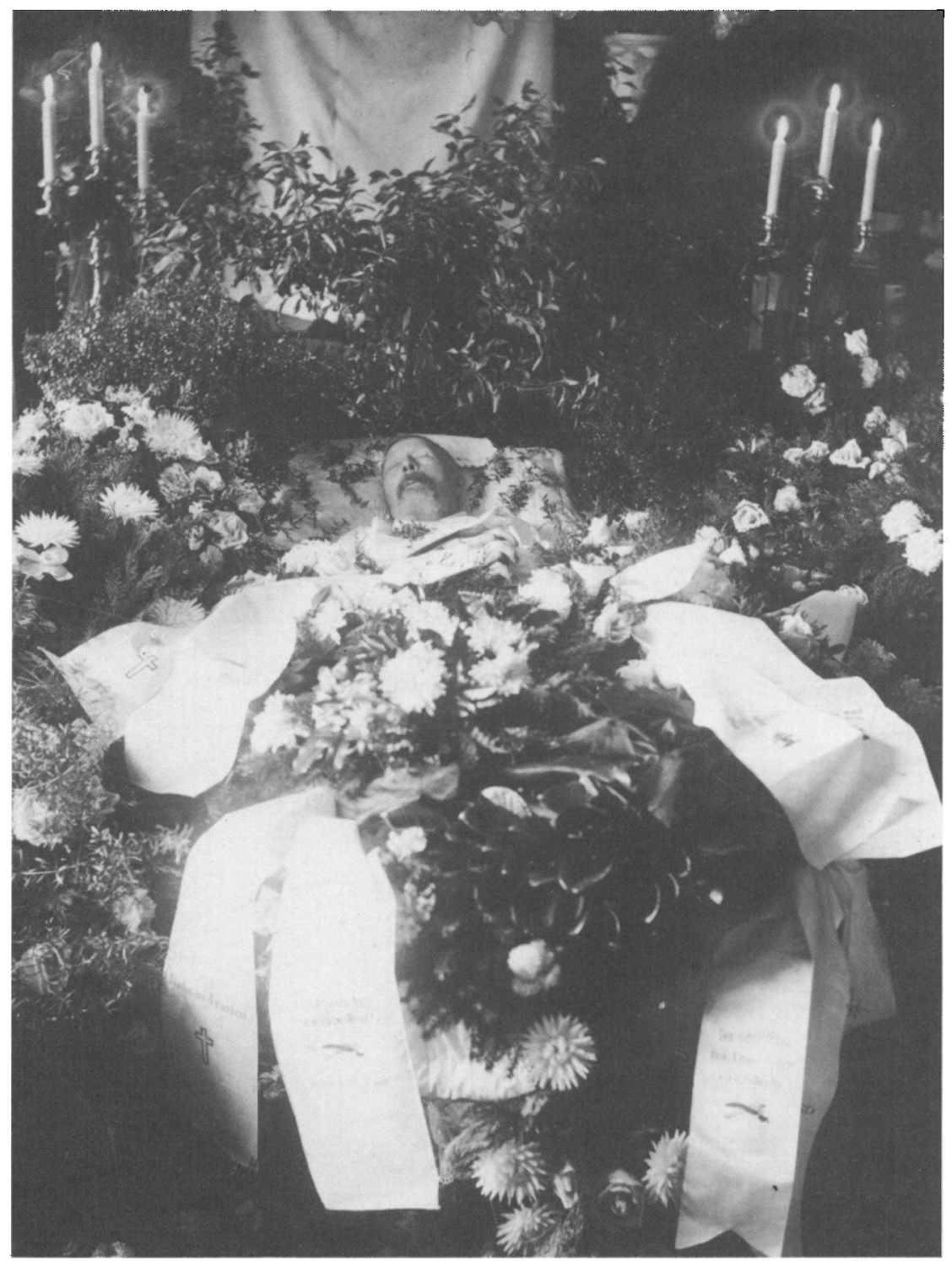

Hans Chr. Iversen dode den 30. november 1916 og blev begravet den 6. december. Den ene sen, Jens var krigsfange i Rusland, den anden, Lorenz var ved vestfronten. Som det var meget almindeligt under krigen, blev den afdede lige som andre, hvis sonner var borte, fotograferet på lit de parade som en sidste hilsen til dem, der ikke kunne vare med til begravelsen. Foto i Historiske Samlinger.

Den 30.november 1916 døde han tidligt morgen af hjertestop i sin seng. Han fik ikke samme mulighed som kollegerne Alfred Petersen, Bergmann og for den 
sags skyld også Claus Eskildsen, som han kendte fra familiesammenkomster i Tønder, efter det tyske nederlag igen at kunne slutte sig til slægtens nationale ståsted. Han oplevede ikke sin yngste søns død ved den franske front 1918, ej heller, at hans hustru i 1920 afgav sin stemme for Danmark, og heller ikke at hans ældste søn Jens, der som ung lærer i Bredebro havde modtaget den officielle belønning, renumerationen, for arbejdet med udbredelsen af tyskheden, nu også tog afstand fra denne, blev lærer i København og efter det nazistiske nederlag i 1945 blev rektor ved det hamborgske skolevæsen ${ }^{29}$.

I sine sidste leveår begyndte Iversen at arbejde med sin slægts historie, et arbejde, der senere er videreført af sønnen Jens i det 156 sider store maskinskrevne manuskript: Af Rugbjerg-Slægten Iversens Saga, som findes i kopi på landsarkivet ${ }^{30}$. Endvidere begyndte han at arbejde med sine egne erindringer, som dog i det væsentlige omfatter optegnelser vedrørende familien. De blev i første omgang skrevet $i$ et hafte $i$ folioformat og senere, 1912, omhyggeligt renskrevet $i$ en bog $i$ fint skindbind, som nu opbevares hos efterkommere $i$ Hamborg. Inden sin død nåede han at få skrevet til tiden omkring 1900, idet et kapitel »Minder fra krigen 1864« ikke er fuldført, men det er dog værd at bemærke, at preusserne her skildres som »fjenden«. Fra 1884 har optegnelserne mere dagbogsagtig karakter, hvilket altså indicerer, at han må have ført dagbog, som han derefter har ført uddrag fra over i sin nye bog. Disse optegnelser vedrører skole og præster i Emmerlev sogn, men først og fremmest begivenheder inden for familien. Indtil 1910 er disse optegnelser med enkelte undtagelser ført på dansk, men derefter overvejende på tysk.

\section{Mine tre seminarieår i Tønder 1869-1872}

Du kære gamle musestad'

du var mig ej sympatisk ...

»O, turde snart vi skilles ad!

Jeg bad tidt exemplarisk.

Jeg stillede mig allerede 1868 til optagelsesprøve i Tønder, tror også ganske vist, at jeg var tilstrækkelig forberedt, men på grund af det til den tid næsten til råhed grænsende såkaldte fuchseri ${ }^{2}$ der dengang fandt en meget ivrig forkæmper i seminarist Høgelund ${ }^{3}$, senere præparandforstander i Apenrade befandt jeg mig under hele prøven i en feberagtig forvirring, der gjorde, at jeg hverken kunne sove eller spise eller drikke, så jeg med rette tør påstå, at alt dette var skyld $i$, at jeg denne gang dumpede.

Jeg mindes fra disse mine første skærsildsdage kun såre lidt. To ret originale 
tildragelser fra hine dage har dog aldrig villet slippe mig af minde. Den ene af disse drejede sig om Jepsen ${ }^{4} \mathrm{i}$ Branderup, senere i mange år lærer i Vollerup, som senere viste sig at være et godt hoved og menneske, men som indtil da kun var vant til at bevæge sig om sin moders kødgryde og småmælet og undseelig, som han også var, ved flere end een lejlighed under prøven afgav en ret komisk rolle. Nu skulle han lige til at vise sit sangtalent. Sanglæreren, herr Johannsen ${ }^{5}$, selv en original, havde ved et vittigt smil om sin lærde mund spurgt den alt andet end smilende examinand, om han kunne synge, da denne med et meget forlegent udtryk $i$ ansigtet og næsten grædende tone til stor moro for den hele forsamling stammende udbrød: »Æ kan kun tre toner" og med sukkende tonefald sang den joniske treklang.

$\mathrm{Nu}$ den anden lille historie, som jeg heller aldrig har kunnet glemme. Hovedrollen i den spiller min senere særdeles gode ven og sidekammerat Chr. Kock $^{6}$ fra Sebbelev på Als (i mange år degn og lærer i Rødding, som jeg pensioneret 1.oktober 1908). Han havde blandt mange små også den store fejl, at han ved hver eneste sand- og usandhed satte en såkaldt stortrumf på. $\mathrm{Nu}$ havde vi lige med spændt opmærksomhed lyttet til seminariedirektorens (Schmidts) ${ }^{7}$ redegørelse for prøvens endelige resultat. Smil resp. forsagthed, alt efter det forskellige resultat for den enkelte stod endnu at læse i de enkeltes ansigter. Den sidste lærer havde endnu næppe forladt salen, da med et sæt og et overmåde stort bulder vor kære Cockseyi, som vi senere med stor forkærlighed kaldte ham og der lige som jeg var falden igennem - stod midt på et af bordene og $i$ en alt andet end grædefærdig tone mere sang end sagde til stor morskab

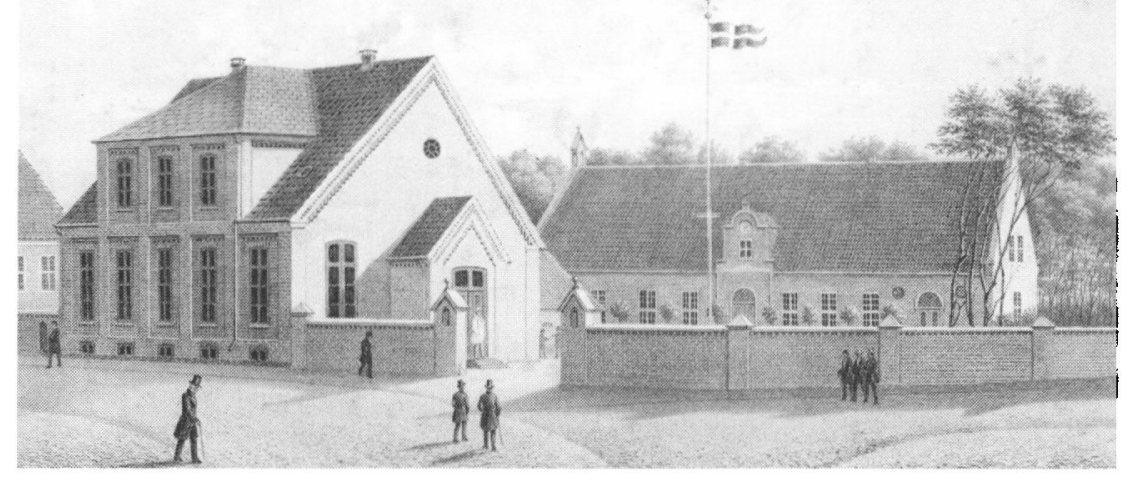

Tonder seminarium o. 1860. I Iversens tid sd anlagget dog noget anderledes ud. Bygningen bagtil var 1865 forhøjet med en etage. I 1905 blev en helt ny statelig seminariebygning taget $i$ brug. Litografi tegnet af A. Ch. Petersen 1860. Udgivet af Em. Barentzen. 
for det med spændt opmarksomhed lyttende publikum: »De gø fanmæ it nove, næste år ve den sam ti møre vi igjen. Du sollst dich fanmæ nicht verbløffen lassen«.

Som sagt, jeg faldt igennem og jeg lovede ved denne lejlighed, at skulle jeg engang blive seminarist, jeg da skulle gøre alt, hvad der stod i min magt for at få denne uskik ${ }^{8}$ afskaffet, hvad der også, især som formand for seminaristforeningen "Harmoni« lykkedes mig. Hvorfor jeg var en stor hader af fukseriet? Nærmest vel fordi jeg anså det for grunden til, at jeg ved første optagelsesprøve faldt igennem (egoisme), men især fordi jeg fra et moralsk standpunkt anså det for en udskejelse (socialisme). Dertil vil jeg rigtignok knytte den bemærkning, at en vis blyhed i disse mine første ungdomsdage udgiorde et særkende for min karakter. Endelig skal det også være sagt, at året 1868 vistnok $\mathrm{i}$ henseende til fukseri var et af de allerværste, idet der havde dannet sig to hinanden skarpt modsatte partier, der førte en hårdnakket kamp mod hverandre, i hvilke ikke blot munden brugtes, men også for at gøre epoke, stokke, navnlig de dengang så meget yndede "totschlägere «'. Vel kom det ikke nogen sinde til virkeligt håndgriberi, men hvad man ikke vovede at byde hinandens rygge, det faldt som drønende brag ned på de stærktbyggede seminarborde. Som en af de vældigste helte $\mathrm{i}$ så henseende på fuchspartiets side kan som sagt nævnes præparandforstander in spe Høgelund i Apenrade, der ved første bekendtskab ikke gjorde det bedste indtryk på mig - en laps ville jeg kalde ham -. En af vore, specielt min, ivrigste forsvarer var Wind, Nr. Løgum ${ }^{10}$, den senere ved sin af regeringen påtænkte Strafversetzung (han havde ved et kirkeligt valg givet sin stemme for en dansksindet kirkeældste) bekendte degn i Handved.

Næste år, altså 1869, om påske stillede jeg mig atter til optagelsesprøve på Tønder Seminarium og denne gang med held.

Første år logerede jeg hos farver Hansen" i Søndergade, en søn af gamle degn emer. Hansen ${ }^{12}$ i Sejerslev, gift med farver Kriegers enke, hos hvem vi fik en såvel god kost som pleje. Søren Krieger ${ }^{13}$, nu praparandforstander i Apenrade, der opholdt sig $\mathrm{i}$ hjemmet, forberedte sig dette år til optagelse på seminariet og bestod påske 1870. Jeg delte stue med Joh. Friedr. Demant ${ }^{14}$ fra Søvang, Højst sogn, der nu ejer sin plejemoders gård sammesteds og helt siden sin afgang fra seminariet har forvaltet elementarklassen i Højst, hvorhen han de mange år har måttet spadsere hver dag frem og tilbage. Han var et flittigt menneske, sparsom helt ud til fingerspidserne, der hverken dengang og næppe nogensinde senere $i$ sit liv har givet en unyttig skilling ud, derfor også nu en af de rigeste mænd i Højst sogn. Han røg ikke - gik, i dette stykke lignede jeg ham Gud ske lov, ikke til værtshus, klædte sig tarveligt, allerhelst i vadmelsklæder og var ved festlige lejligheder med nød og næppe at formå til at tage 


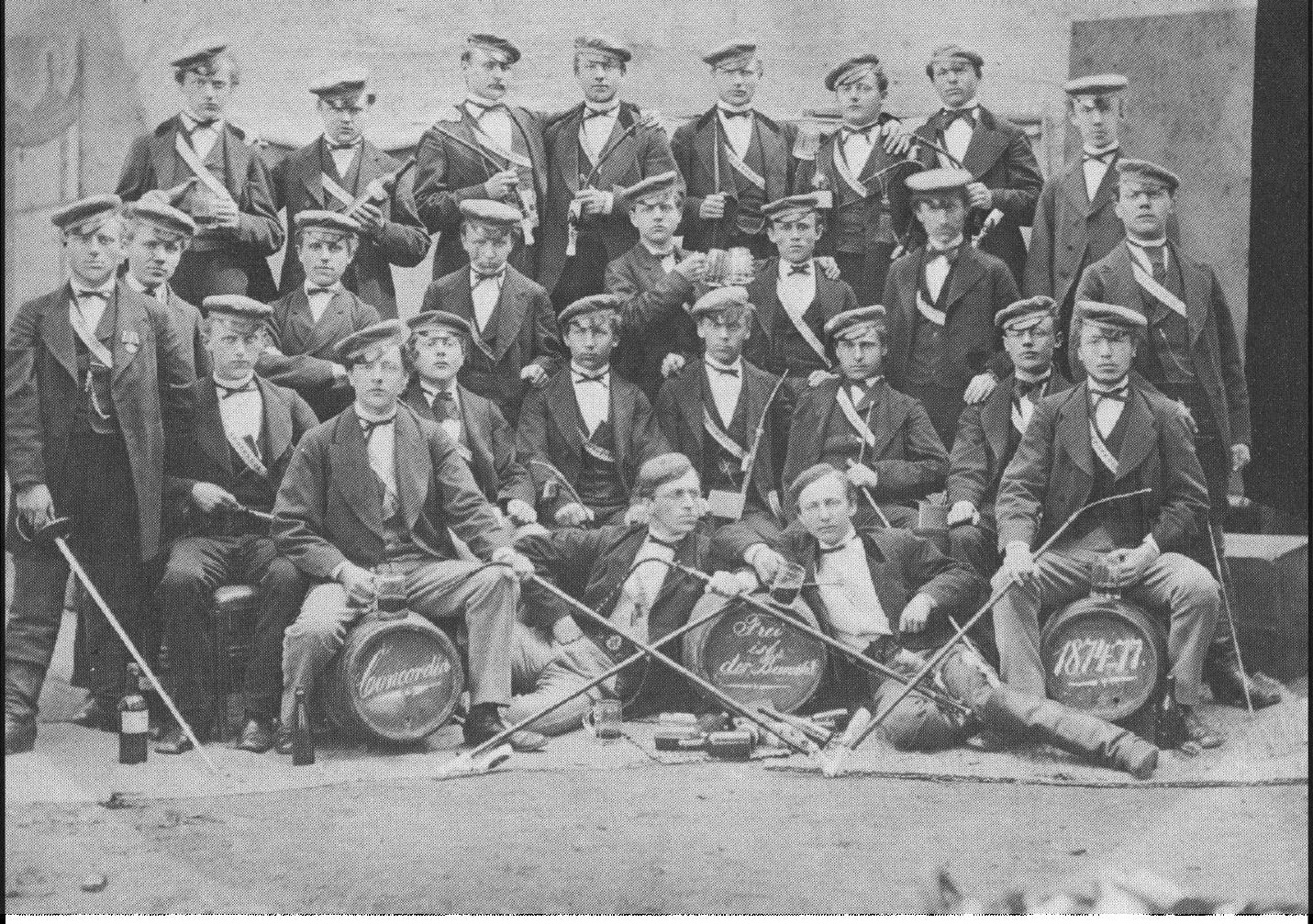

Tonder seminarister 1874-77. Her gengivet efter original på Tonder Statsseminarium, jvfr. L. S. Ravn: Trak af folkeskolens historie i Nordslesvig 1864-1920 (1981) s. 89.

hvid krave på - men som sagt, han var en dygtig seminarist og et bravt menneske, som man ved nærmere bekendtskab måtte komme til at agte og elske, selv om hans kammerater på grund af de små unoder og særheder i hans optræden nu og da afnødte dem et lille ikke så slet ment smil. Mine øvrige klassekommilitoner vare:

Peder Andersen ${ }^{15}$ fra Abild, i mange henseender såvel på legeme som sjæl en original. Farveblind, som han var, havde han et ejendommeligt mat blik og ret kejtede manerer, men var et lyst hoved og et stykke af en digter. Til nogle af hans skæmteviser, der sædvanligvis, alt efter som lejlighed gaves, forfattedes på stående fod og som oftest havde til hensigt at drille vor latinske Ravn ${ }^{16}$, der uagtet han var godt lidt af kammeraterne, ofte skulle være offer for uskyldigt drilleri - har jeg ligeledes imprumptu på den store nodetavle sat melodier, der da gjort til bedste ved Ravns indtræden $i$ klassen (han var gerne en af de sidste, der mødte) nok kunne have til følge, at han bestormede os med kul- og tørvestumper, så vi alle, så godt vi kunne, måtte søge dækning under bordene. Andersen var, sært nok, ikke videre godt lidt af kammeraterne 
i almindelighed, og han var den eneste til min tid, som seminariets B-afdeling, - der havde sine lokaler foroven, - gav et såkaldt triumftog, der kun i sin sorteste modsætning svarede til sit navn. Et sådant bestod deri, at pågældende, uagtet al hans modstand, blev løftet op på ryggen på et par af de stærkeste blandt kammeraterne, der så satte sig $\mathrm{i}$ bevægelse gennem alle klasser, efterfulgt af de støjende seminarister, der da kappedes om at tildele exekventens bagkrop de tilbørlige prygl. Der blev sagt, at en ret indviklet elskovshistorie havde været årsagen til den ejendommelige spidsrod. Jeg kunne ganske godt lide Andersen og tog derfor ingen del $\mathrm{i}$ optoget, som jeg ingenlunde billigede. Andersen opgav forholdsvis tidligt den pædagogiske løbebane (inden vort 25årige embedsjubilæum, som vi fejrede i Tønder) og blev landmand. En søn af ham studerer, såvidt jeg ved, teologi"

Autzen $^{18}$, der endnu tidligere forlod lærervejen (der sagdes, at han var gået denne vej for at slippe soldat med 6 uger) er ligeledes en velsitueret gårdmand.

Boysen ${ }^{19}$, der ejendommeligt nok, da han kom på seminariet allerede var gift og havde kostgængere, døde som lærer $\mathrm{i}$ Tirslund.

Have $^{20}$ var min højre og Jessen ${ }^{21}$, indtil han efter et års forløb på grund af sit ret udsvævende levnet blev forvist fra seminariet, min venstre sidemand, hvis plads så Chr.Kock fra Sebbelev på Als indtog. Lorenzen, Nørre Løgum ${ }^{22}$, der tilsidst var degn og lærer i Oksbøl på Als, tog sig ved et revolverskud selv af dage. Lorenzen, Bajstrup ${ }^{23}$, med hvem Demant og jeg, især ved repeteringen, læste en hel del sammen, og som på grund af sin overordentlige store flid fik første karakter, var i mange år andenlærer i Højer og pensioneredes som jeg d. 1.oktober 1908.

Ravn - Ultangmølle, der nogle år før sin indtræden på seminariet havde frekventeret latinskolen i Haderslev og derfor af sine kammerater måtte døje en hel del ikke så slet mente satirer, som til eksempel "Latin hjælper et menneske meget i verden« (Holbergs komedier), hørte ikke til de flittige og indfandt sig ofte hos Demant og mig, for, når han, som så tit skete, ikke var fulgt med i undervisningen, at hente hjælp hos os. Da han var et godt gemyt og besad en del mutterwit ${ }^{24}$, var han just ikke uvelkommen hos os, og vi drev da $\mathrm{i}$ reglen en times tid hen med munter skæmt. Han døde kort efter sin dimission fra seminariet. Svane ${ }^{25}$ var ikke godt lidt af sine kammerater og Velz ${ }^{26}$, der ellers var et godt menneske, men holdt sig for meget til Svane, isolerede sig på denne måde fra os andre. Han døde for en del år siden. Den eneste af mine kammerater, der endnu er i embede, er Demant, Søvang. Alle de andre er enten døde eller pensionerede.

Lærerne i den såkaldte danske afdeling (B) var: Seminariedirektor Schmidt ${ }^{27}$, der i mit tredie seminarieår blev præst og senere tillige provst i Svenstrup på Als. Han var ved lejligheder streng og tildels opfarende, men en meget dygtig 
Niels Schmidt, 1826-1901, seminariets forstander 1864-7I, derefter prast og provst pd Als. Foto pd Tonder Statsseminarium.

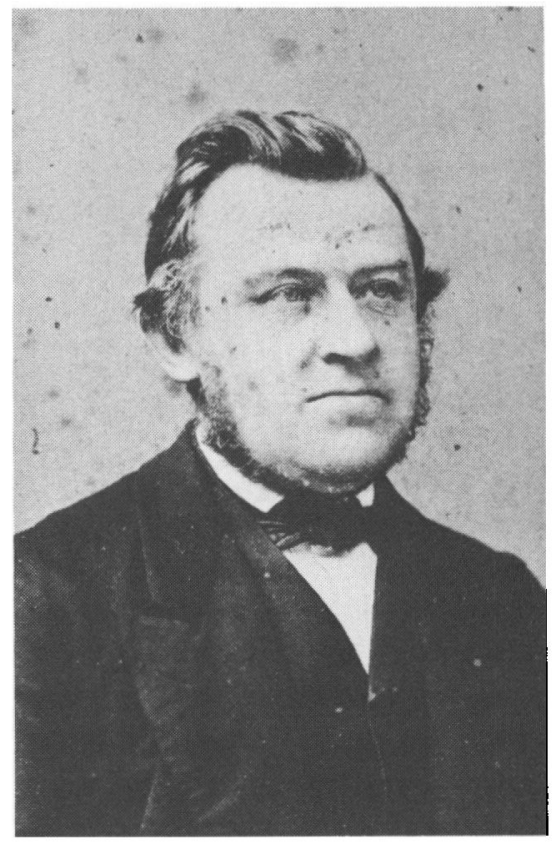

lærer og derfor også skattet og afholdt. I mit andet seminarieår nød vor klasse en fortrinlig religionsundervisning hos ham. En søn af ham er fredsforeningsformand ${ }^{28}$.

Pastor $\mathrm{Aye}^{29}$, hvis hele undervisning bestod i diktat, havde religion og pædagogik og var formedelst hans utilgivelige dovenskab en dårlig lærer og formedelst sin partiskhed ilde anset. Han var den eneste lærer til sin tid, der midt $i$ en undervisningstime af vor klasse blev udpeben og virkelig måtte forlade klassen. Han kom i mit andet seminarieår til Medelby. En søn af ham, advokat Eye i Flensborg, blev for nogle år siden skudt i en duel.

Pastor Engel ${ }^{30}$, Eyes efterfølger, var med hensyn til undervisningen ikke stort bedre, så at vi i religion og pædagogik med undtagelse af den tid, vi havde direktor Schmidt, har haft en under al kritik dårlig undervisning. Hans undervisningsmåde var ligeledes diktat og hans sætninger var i reglen så lange og lærde og opstyltede, at han vel næppe undertiden selv kunne hitte rede på dem. De theologiske kandidater, der hospiterede på seminariet samme år, forstod ham efter deres udsagte ofte ligesålidt som vi ikke-teologer. Mit hæfte fra den tid er desværre gået tabt for mig, ellers kunne det have været interessant at have givet et par eksempler på hans kraftsætninger. Han blev senere præst på Als og skal have været en ret dygtig prædikant. 
Rickmers ${ }^{31}$, degnen fra Medelby, som vi havde i mathematik, historie og geografi, var et hjertensgodt menneske og et mønster af en skolemester. Hans kundskaber rakte ikke særdeles vidt; han gav derfor ikke meget, men det han gav, gav han - praktisk som han var - $i$ en form, så enhver kunne følge med. Han talte så dårligt dansk, at vi i førstningen måtte gøre os stærke for ikke at briste i latter. (»Kan De denne sætning på tavlen henkaste!«) Han henlevede sine sidste dage i Flensborg og blev en meget gammel mand.

Petersen $^{32}$, uden al tvivl vor bedste lærer, senere kredsskoleinspektør i Apenrade, gav en fortrinlig undervisning i dansk sprog (Meiers grammatik) og litteratur, der endnu til den tid dreves som et hovedfag. Ved siden af sin dygtighed var han tillige en ædel karakter og derfor højagtet og elsket.

Johannsen ${ }^{33}$, der var lærer i musik og gymnastik, i vakancen også tillige i fysik, kan ikke fornægtes dygtighed som sådan, men han var, vistnok begrundet $\mathrm{i}$ ægteskabelige og andre familiære misligheder, ofte ret brutal og havde til andre tider, uberegnelig som han var, passion til alt for meget at nedlade sig til seminaristerne og selv $i$ undervisningstimerne at drive allotrier ${ }^{34}$ og narrestreger med dem. Han var et stykke af en håndværker og ofte var han, når man traf ham på gaden - formedelst sin for en seminarielærer ofte kun lidet passende klædedragt - ikke til at skelne fra en murmester. Iøvrigt var han ikke ilde lidt af os, men på den tilbørlige ærbødighed mod ham fra vor side måtte det jo desværre under sådanne omstændigheder skorte.

Papa Wilms ${ }^{35}$, som han i almindelighed kaldtes og som egentlig hørte Abt. A til, var vor lærer $i$ botanik og zoologi, det eneste fag (med undtagelse af måske det allersidste år) som vi havde i det tyske sprog. Han havde på grund af sin barnlige, næsten til barnagtighed grænsende hjertensgodhed og sin ejendommelighed $i$ aldrig at komme fremad $i$ sin undervisning (hvorfor vi heller ikke lærte noget hos ham) meget svært ved at opretholde disciplinen, og følte han sig på grund heraf nu og da fornærmet, kunne han faktisk omtrent en hel undervisningstime igennem hulke og græde som et barn. Da han som sagt var et hjertensgodt menneske, vogtede vi os af yderste evne for at lade det komme så vidt; dog kunne det næppe ganske undgås.

Büsing ${ }^{36}$ var vor lærer i havedyrkning. Skønt kun gartner var han slet ikke udygtig $\mathrm{i}$ at undervise, men på grund af vor ulyst til faget og vel også på grund deraf, at han selv ikke ret forstod at anspore os til at tage ordentlig hånd $\mathrm{i}$ arbejdet (han var næppe selv ivrig nok $\mathrm{i}$ havedyrkningen, men havde, som det blev sagt, mere lyst til at vove sin lykke $i$ et temmeligt højt spil kort) fik vi lidet eller intet lært $i$ havekultur; alligevel bragte jeg det ved min afgangseksamen - ganske uden egen værdighed og fortjeneste - til et "meget godt".

Richter $^{37}$, senere seminariedirektor først i Tønder og dernæst i Augusten- 
Carl Friedrich Richter, 1821-90, seminariets forstander 1871-78, derefter for Augustenborg kvindeseminarium. Her gengivet efter foto pd Tonder Statsseminarium.

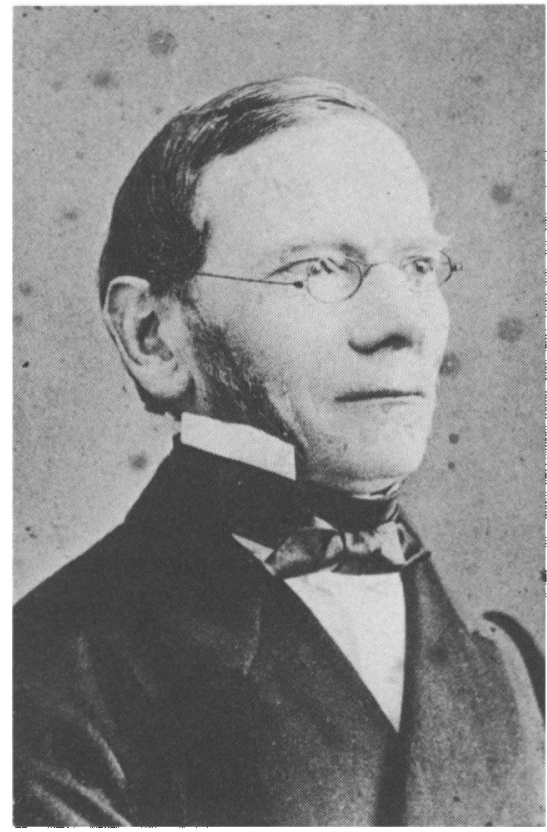

borg, var ganske vist en meget betydelig pædagog, men utilbørlig doven og gav derfor en højst tarvelig undervisning i tysk sprog, der indskrænkedes til et par timer om ugen og for det meste bestod i simpel diktat og oversættelse, hvilket kun lidt kunne bidrage til at udvide vort kendskab til det tyske sprog. Det sidste år havde vi dog ved siden heraf en del fag med tysk undervisningssprog som historie, geografi og naturfagene.

$\mathrm{Krause}^{38}$, der ligesom sidstnævnte hørte Abt. A til, gav undervisning i skønskrivning. Han ville gerne spille den fine mand og havde en form $i$ at bukke og skrabe. Dog var han som musiklærer for den tyske afdeling vistnok grundigere og dygtigere end vor Johannsen.

Provinsialskoleråd var til den tid dr. Schneider ${ }^{39}$, en legemlig kun lille, åndelig derimod betydelig mand. Generalsuperintendent var dr.Godt ${ }^{40}$ og regeringsog skoleråd Matzen ${ }^{4}$, forhenværende præst i Bylderup. Alle tre sidstnævnte hørte med til vort eksaminationskollegium.

Lige før jeg skulle gå op til min første årseksamen (jeg boede da lige over for seminariet hos en gæstgiver Blickenberg) skete der for min hjemby Bredebro en tildragelse, som ej skal forbigås uden nogle få optegnelser. Ligesom jeg skulle begynde den første dags eksamensarbejder og om morgen tidligt var begivet mig på vej ud efter Abild forbi Schweizerhalle for til det anstrengende arbejde 
at opfriske mig ved en spadseretur, traf jeg undervejs på Chr.Hansen fra Svanstrup, der skulle til kreaturmarked i Tønder og nu fortalte mig om den store brand, der natten forud havde hærget i Bredebro og lagt mange huse øde, deriblandt skolen, medens den efter nogen truen havde skånet mit kære hjem, degneboligen ${ }^{42}$.

En anden oplevelse fra samme år skal også værdiges et par ord. Efter sommerferien 1870 gav jeg på anbefaling af seminariedirektoren timer en tidlang i den danske privatskole i Tønder, der indtil da havde haft til bestyrer den bekendte dansksindede lærer Tørsleff ${ }^{43}$. Denne havde, blev der sagt, på det for kort tid siden stedfundne, i politisk henseende ret bevægede dyrskue $\mathrm{i}$ Visby udbragt en skål for Danmark og måtte for ikke at falde i de samme gensdarmers hænder, som $i$ august måned samme år på generalgouvernør Falkensteins anordning førte Krüger, Willemoes, Ley, Beck og pastor Schmidt, Visby til fangenskab i Königsberg. Der blev fra den modsatte side påstået, at Tørsleff ikke havde udbragt Danmarks, men damernes skål. Hvad de andre fem herrer bleve beskyldt for, mindes jeg ikke mere ${ }^{44}$.

Under mit ophold i Tønder fejredes d. 23.februar 1871 mine kære forældres sølvbryllup, der dog kun indskrænkede sig til en festlighed for de nærmeste naboer og venner. På grund af at repetition til den forestående anden årseksamen havde begyndt, blev jeg i Tønder for ikke at forstyrres i mit vigtige arbejde. Såvidt jeg husker, har jeg ikke en eneste gang forlangt orlov fra seminariet.

Det første år logerede Joh. Fr.Demant fra Søvang og jeg, som før sagt, sammen hos farver Hansen ved Sønderporten. Samme Hansen ... var gift med farver Kriegers enke, altså stedfader til nuværende præparandforstander Krieger i Apenrade, der dette år i hjemmet forberedte sig til optagelse på seminariet.

I det andet seminarieår boede jeg ligeover for seminariet hos en privatier Blickenberg ${ }^{45}$, der her boede til leje. I samme hus, men på forskellig stue, boede en seminarhospitant Chemnitz, en broder til digteren af SchleswigHolstein-visen ${ }^{46}$, der dette år forberedte sig til autodidakteksamen på seminariet og med hvem jeg nu og da fik mig et spil skat. Blickenberg flyttede senere til Vestergade til et hus til vest for rebslager Reinhold $t^{47}$, hvor jeg et halvt år boede sammen med Madsen-Borrig ${ }^{48}$, jeg forneden, Madsen derimod foroven.

Det tredie år flyttede Demant og jeg atter sammen og boede da hos træhandler Andresen ${ }^{49}$ i Vestergaden. I samme hus arbejdede dette år nuværende degn og førstelærer Riggelsen ${ }^{50}$ i Højer som skriver hos herredsfoged Grünfeld ${ }^{51}$, der havde sit kontor foroven. Dog lærte vi to hinanden egentlig at kende, da han blev min eftermand som andenlærer i Rabsted og allermest da vi boede i S. Sejerslev, hvor vi jevnligt kom sammen med den kære Riggelsen'ske familie 


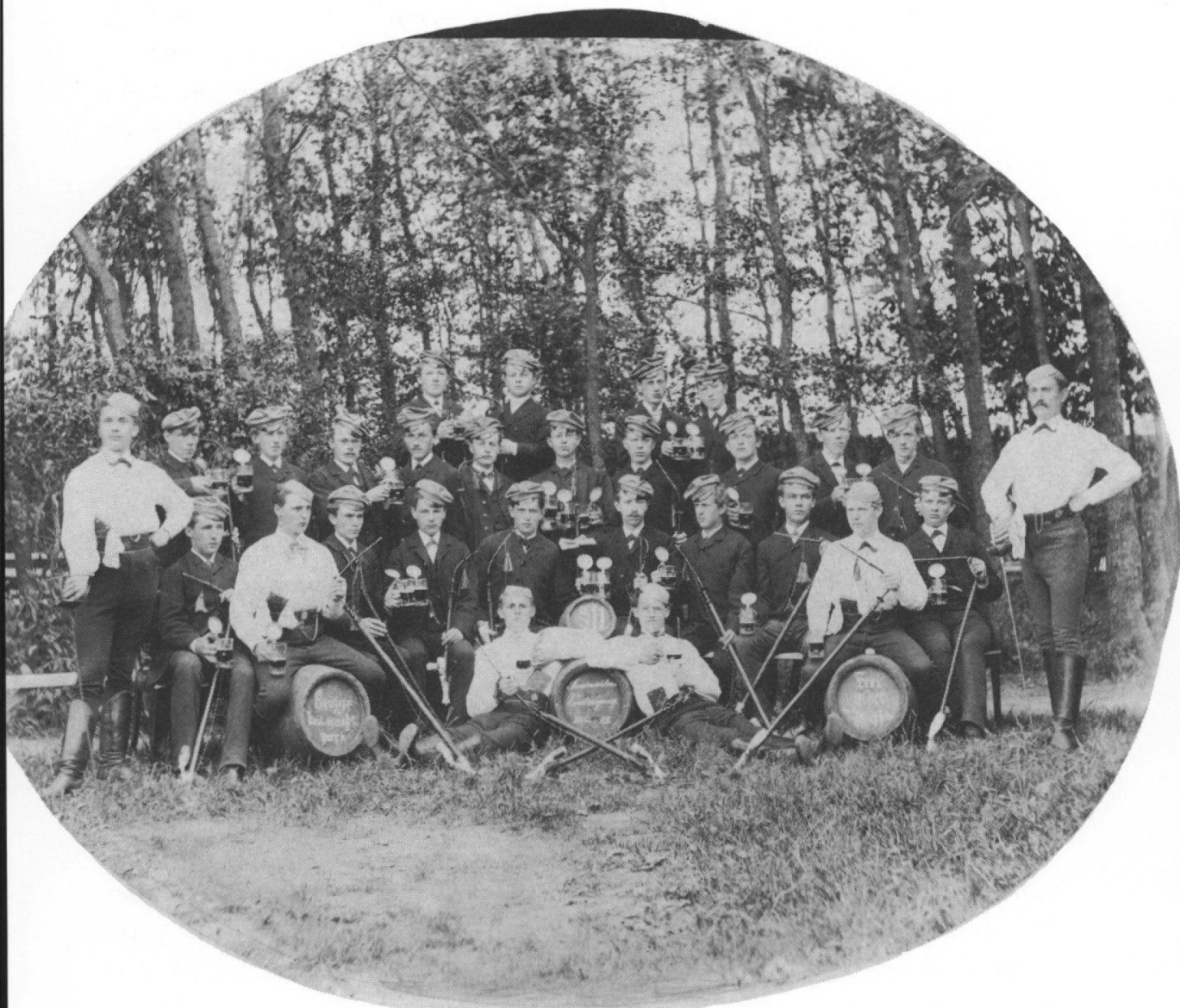

Hans Chr. Iversen fremhaver, at seminaristerne $i$ den danske afdeling $i$ hans tid forte et meget sobert levned. Et indiryk af den burschikose stil, som ellers var pd mode, giver dette billede af Tonderseminarister i Schweizerhalles have o. 1889. Den danske afdeling var da nogle dir i forvejen flyttet til Haderslev. Der er ikke mangel på oltonder, olkrus og lange piber. Her gengivet efter det originale foto pd Tonder Statsseminarium.

i Højer. I alle tre pensionater havde jeg det $\mathrm{i}$ alle henseender upåklageligt såvel folkene som kost og stue var til fuldkommen tilfredshed.

Opholdet på seminariet, hvor man med så mange bånd var knyttet sammen med lutter unge, livsglade mennesker, var $i$ det hele taget ret behageligt, dog længtes man efter at blive færdig og rejse som fri mand ud $i$ den vide verden med evt. en ret god karakter i lommen. Jeg havde ikke just svært ved at følge med $\mathrm{i}$ undervisningen, læste jævnligt ret flittigt og anstrengte mig især ved den forud for enhver årseksamen gående repetition, som vi gerne begyndte $1 / 4$ års 
tid i forvejen. Jeg læste da sammen med Demant, Lorenzen-Bajstrup, somme tider desuden endnu med Lorenzen-N. Løgum og Kock. Vi foredrog da afvekslende for hinanden af det på vore egne stuer gennemgåede stof indtil henimod midnat og gjorde da ofte efter ret anstrengende arbejde i fællesskab en spadsere - resp. løbetur omkring byen langs det såkaldte borgerdige, hvorefter vi da nød en sød og velgørende søvn.

Den såkaldte danske afdeling gjaldt til min tid at være overordentlig solid og bortødslede ikke sin kostbare tid ved værtshusene; de eneste unyttige penge, om man så tør kalde det, jeg anvendte, var, når vi (de fornævnte og jeg) en sjælden gang imellem, efter ret anstrengende arbejde, tillod os den flothed at gå til konditor Hamerich ${ }^{52}$ for at nyde en æggesnaps eller et par kager. Seminaristerne i den tyske afdeling havde derimod ord for at være lidt udsvævende. Dog gaves der også i vor afdeling enkelte, der alt for gerne færdedes $i$ danselokalerne og krostuerne. Også i vor klasse fandtes desværre en sådan, men også den eneste, min sidekammerat Jessen-Rinkenæs ${ }^{53}$, der derfor også allerede det første år blev forvist fra seminariet. I øvrigt var samme Jessen, hvad vistnok er tilfældet med sådanne øjebliksmennesker, på grund af sin mutterwitz og sit gode sindelag afholdt af os alle. Den forste og, såvidt jeg mindes, eneste ærlige rus Demant, Lorenzen-Bajstrup og jeg drak os under opholdet på seminariet, havde vi denne vor gode ven Jessen at takke for, der til sin fødselsdag på sin stue trakterede os med en bowle punch. Det morsomme ved den hele historie, der i grunden dog næppe var så ret morsom, var, at da vi i al huj og hast havde drukket en tre til fem glas af den søde vare, havde vi fået nok af herligheden og måtte, syge som vi nu var, da hjem på vore stuer for - ikke af nysgerrighed - at få kontrolleret, hvormeget vi af de våde varer havde drukket for meget. Demant kom for skade til at gøre det på vort stuegulv; jeg derimod havde klogeligen opgjort regnskabet $i$ den fri natur.

Vi havde de tre år, jeg var på seminariet en forening "Harmonien«, der det sidste år blev lidt omdannet og nu hed Phønix ${ }^{54}$. Det sidste år var jeg dens formand. Vore møder holdtes på Schweizerhalle. Hensigten med disse møder var underholdning med foredrag og flerstemmig sang.

Jeg har kun en eneste gang i den tid, jeg har været på seminariet været til dans, et seminaristbal på Schweizerhalle.

Efter hver optagelsesprøve fejrede vi en såkaldt fuchsschmaus, hvortil seminarielærerne var indbudne. Der gaves da komiske småstykker til bedste af seminaristerne. Af komikere ved sådanne lejligheder mindes jeg endnu især gamle Svane ${ }^{55}$, en fætter til min klassekammerat, Lassen-Lund ${ }^{56}$, Kock ${ }^{57}$, lille Petersen (nu degn i Rabsted) ${ }^{58}$.

Seminaristerne i Abt. B var ikke blot dansktalende, men også næsten uundtagelsesvis dansksindede. Dog var de fleste i så henseende så nogenlunde 
moderate. Af de eksalterede kan især nævnes de senere redaktører Jessen (Flensborg Avis) ${ }^{99}$ og Mathiesen (Dannevirke) ${ }^{60}$, begge to to klasser bag os.

En gang i måneden plejede jeg i reglen at besøge mine kære i hjemmet og havde da også imellem kammerater med. Der kørtes da gerne den ene vej med dagvognen, en stor skrumlekasse, der hver dag gjorde turen frem og tilbage fra Tønder til Ribe; den ene vej toges sædvanlig til fods.

Jeg har senere ofte undret mig over, at vi på seminariet ikke i nogen måde hindredes $i$ at nære danske sympatier, men snarere, især $i$ sangundervisningen, styrkedes deri. Sange som "Vort modersmål er dejligt«, "Moders navn har en himmelslyd«, "Vort land, vort land, vort fosterland « hørte med til vort sangrepertoire på seminariet.

I mit andet seminarieår udbrød krigen mellem Tyskland og Frankrig, hvortil ikke så få af Abt. A meldte sig frivillig, derimod ingen af Abt. B. Imidlertid gik, så vidt jeg husker, undervisningen på seminariet sin rolige gang. De fra krigen lykkeligt tilbagevendende kammerater, af hvilken ingen faldt, skænkedes krigsåret og fik ved afgangseksamen forholdsvis ypperlige karakterer, een, Iversen - Munkbrarup endog 1. karakter ${ }^{61}$.

Ved vor afgang fra seminariet fik Demant og jeg tildelt samme karakter, nemlig 2. karakter med rosværdig udmærkelse. Vor vært og værtinde ønskede os til lykke hertil ved en flaske portvin.

\section{NOTER OG HENVISNINGER}

I noterne er anvendt følgende forkortelser:

Ravn =L.S. Ravn: Lærerne i Nordslesvig ca. 1814-1920, 1978.

Sem-Stat $=$ Tønder Seminarie-Stat ved Jens Lampe, Erik Larsen og Asger Nyholm, 1963.

Sem-Stat $S=$ Lærerfortegnelsen i Sem-Stat.

\section{INDLEDNING OG LEVNEDSKILDRING}

1. Sem-Stat, s. 27lff findes en meget udførlig kildefortegnelse til seminariets historie. Her skal som de vasentligste kilder blot nævnes:

H. Eckert: Gründung und Entwicklung des königlichen evangelischen Schullehrer-Seminars in Tondern, 1888.

A. Siemonsen: 123 Jahre Deutsches Lehrerseminar in Tondern, 1925.

Emil Albeck og Claus Eskildsen: Tonder Statsseminariums Historie. 1788-1938, 1938.

Morten Bredsdorff og Erling Brahm: Tønder Statsseminarium og Øvelsesskole, 1945.

L.S.Ravn: Tønder seminarium. Den danske afdeling 1864-1884, Sønderjysk Månedsskrift 1967, s. 73-90.

J.H.Schmidts erindringer fra seminarieårene findes i Årsskrift for gamle og nuværende Elever fra Tonder Statsseminarium 1946, s. 45-49.

Matthias Matthiesens erindringer findes i Flensborg Avis 1931 14/6; jfr. A. Svensson: Redaktør J. Jessen, Flensborg Avis I, s. 27-32 og Jens Lampe i seminariets årsskrift 1961, s. 7-11. 
Niels Peter Olsen: Landsbydreng og lærer i Nordslesvig i tiden fra 1864 til sprogforordningen 1888, Sønderjyske Årbøger 1956, s. 105-189.

Jens Andersen Jensens utrykte erindringer beror i Landsarkivet, Aabenraa.

2. Se Sønderjysk Månedsskrift 1958, s. 254ff og Ravn nr. 1195.

3. De personalhistoriske oplysninger vedr. Iversen hidrører hovedsagelig fra den i det følgende omtalte utrykte erindringsbog, hvoraf kopi findes på landsarkivet, og hvorfra uddragene om seminarieopholdet $i$ Tander er taget.

4. Georg Friedrich Jessen, 1811-83, præst i Abild 1841-64, i Nordborg 1864-73, i Ulkebøl 1873-83, 1874 provst over Als Sønder herreds provsti.

5. Broder Andreas Ratenburg, 1850-1933, landmand i Borg, Brede sogn.

6. Anders Nissen, 1823-92, var ligesom Jens Iversen dimitteret fra Skårup seminarium, Ravn nr. 2121.

7. Ravn nr. 2735 og Sem-Stat nr. 1423. Sell var gift med en datter af provst Jessen.

8. Christen Christensen, 1807-70, Ravn nr. 420 og Sem-Stat nr. 625.

9. Andreas Iversen, 1813-90, død som rentier i Bredebro, stifter af det Iversen'ske legat i Breklum.

10. Marie Cathrine Iversen, 1848-1906, gift 1880 med gårdejer Thies Steenholdt Rasmussen i Solderup, 1847-1920.

11. Ingeborg Helene Holt, 1858-1959 var datter af gårdejer Lorenz Peter Holt og hustru Hanne Marie, f. Petersen i Åspe, Brede sogn.

12. Christen Hansen Lausten, død 1911, 87 år gammel.

13. Theodor Feddersen, 1839-1915, ejer af Søndergårde og Kogsbøl fra 1883, amtsforstander til ca. 1907.

14. Skrivelsen er gengivet i Jens Iversen: Af Rugbjerg-Slægten Iversens saga, maskinskrevet manuskript på landsarkivet og i privateje i lidt forskellige udformninger. I landsarkivets eksemplar s. $132 \mathrm{f}$, i andre eksemplarer s. 89.

15. Hafterne med disse sange er i privateje.

15a.Chr. Aug. Burgdorf, d. 1896 var kredsskoleinspektør i Tonder amts distrikt II 1878-86 og 1888-96. Johannes Mosehus, var det 1886-88, derefter i A benrå 1888-1912. Burgdorf efterfulgtes af Aug. Friedr.Emil Krage. Der var dog ved embedsledighed nogle konstitueringer. Se L.S. Ravn: Træk af folkeskolens historie i Nordslesvig 1814-1920, s. 120fr. Oplysningerne her er dog ikke helt fuldstændige og korrekte, bl.a. skelner Ravn ikke mellem de forskellige distrikter i Tønder amt.

16. Den fordrukne præst var Eduard Adolf Asmussen, 1836-1912, præst i Emmerlev sogn 1868-93. Ang. Asmussen se endv. Jon. Smiths utrykte erindringer.

17. Konsistorium i Kiel, Nr. Tønder provsti, Emmerlev sogn.

18. Tender landrådsarkiv nr. 595.

19. Vestkysten $20 / 61987$.

19a.Sønderjyske Årbøger 1956, s. 156. Jfr. i denne forbindelse også Ravn s. 513 og 527 .

20. L. Sass, den slesvigske regerings tilsynsførende skoleråd 1888-1914. Se L.S.Ravn: Træk af folkeskolens historie i Nordslesvig 1864-1920, 1981, s. 114. Af Sdr. Sejerslev skolekrønike fremgår iøvrigt, at Sass allerede ved en inspektion 1893 havde flere ting at kritisere, bl.a., at Iversen talte dårlig tysk.

21. Ravn nr. 1319, Sem-Stat nr. 1503. Se endv. Peter I.Iversen: De gode gamle dage, s. 8 og 15.

22. Ravn nr. 1362, Sem-Stat nr. 1444.

23. Ravn nr. 1336, Sem-Stat nr. 1881.

24. Ravn nr. 2265, Sem-Stat nr. 2356.

25. Ravn nr. 179.

26. G. Japsen: Den fejlslagne germanisering, s. 172-76.

27. Skrædermester Peter Ingwer Petersen, 1857-1935, der var rådmand, Stadtrat 1897-1922. Se Tender byarkiv: Sager til aktplan nr. $27 \mathrm{G} 1 \mathrm{~b}$.

28. I privateje.

29. Ravn nr. 1196, Sem-Stat nr. 2803. Angående lærernes vanskelige nationale balancegang kan iøvrigt bemærkes, at Iversens et par år yngre kollega Jens Andersen Jensen i Skærbæk, der af 
Nic. Svendsen skildres som »kernedansk «, både var medlem af den tyske forening og krigerforeningen samt ydede et krigslån på $1000 \mathrm{mk}$. Iversen nøjedes dog med at være med $\mathrm{i}$ pastor Schmidts fredsforening.

30. Jfr. note 14; endvidere findes på landsarkivet en stor anetavle for Jens Iversens børn.

\section{MINE TRE SEMINARIEÅ I TøNDER}

1. En lokal poet har engang skrevet en sang "Musenstadt an der Wiedau«, se Sdj. Årb. 1956, s. 164. Sangen findes ikke i Commers-Buch der Seminaristen zu Tondern 1888 eller 1896.

2. Fuchseri. Fuchs er ræv. Fuchseri kan vel nærmest oversættes ved rusdåb. Ang. fænomenet se Sdj. Årb. 1956, s. $136 \mathrm{f}$ og H. Siemonsen: 123 Jahre deutsches Lehrerseminar in Tondern 1925, s. $95 \mathrm{ff}$.

3. Peter Hansen Høgelund, dim. 1868, Sem-Stat nr. 1500, Ravn nr. 1158.

4. Andreas Ditlef Jepsen, dim. 1871, Sem-Stat 1605, Ravn nr. 1345.

5. Se note 33 .

6. Christian Hansen Kock, dim. 1872, Sem-Stat nr. 1641, Ravn nr. 1611.

7. Se note 27.

8. D.v.s. fuchseriet.

9. D.v.s. knippel med indlagt blyklump.

10. Hans Pedersen Wind, dim. 1870, Sem-Stat nr. 1585, Ravn nr. 3054b.

11. Andreas Hansen var søn af farver Nis Hansen og Hedvig Iversen. Han blev gift 10/10 1857 med Charlotte Caroline Wilhelmine Krieger, f. Kreutz, hvis forste ægtefælle var porcelænshandler Georg Herman Krieger. Iversens oplysning altså ukorrekt.

12. Johannes Hansen, se Ravn nr. 968.

13. Philipp Heinrich Krieger, dim. 1873, Sem-Stat S. 48, Ravn nr. 1635.

14. Johan Frederik Demant, dim. 1872, Sem-Stat 1638, Ravn nr. 560. Joh. Fred. D.'s søn Johannes Karl Frederik D. blev gift med Hans Chr. Iversens niece Christine, født Rasmussen fra Solderup.

15. Peder Andersen, dim. 1872, Sem-Stat nr. 1635, Ravn nr. 39.

16. Hans Christensen Ravn, dim. 1872, Sem-Stat nr. 1644.

17. Peter Andersen, 1882-1925, teol. cand. Kiel 1911, præst i Holbøl 1912-25.

18. Jeppe Autzen, dim. 1872, Sem-Stat nr. 1636.

19. Hans Theodor Ferdinand Boysen, dim. 1872, Sem-Stat nr. 1637, Ravn nr. 255.

20. Ferdinand Nissen Have, dim. 1872, Sem-Stat nr. 1639, Ravn nr. 1062.

21. Formentlig Jes Jessen, søn af gårdmand i Rinkenæs Jes Johansen Jessen, født i Varnæs 1848.

22. Jergen Nissen Lorenzen, dim. 1872, Sem-Stat nr. 1643, Ravn nr. 1805.

23. Iver Peter Lorenzen, dim. 1872, Sem-Stat nr. 1642, Ravn nr. 1800.

24. Naturligt, muntert vid.

25. Claus Jensen Svane, dim. 1872, Sem-Stat nr. 1645, Ravn nr. 2821.

26. Jens Nielsen Weltz, dim. 1872, Sem-Stat nr. 1646, Ravn nr. 3016.

27. Niels Schmidt, Sem-Stat S nr. 33, jfr. smst. s. 13.

28. Pastor Johs. Schmidt, Vodder, medlem af Folketinget 1920-39.

29. Jacob Friedrich Theodor Aye, Sem-Stat S nr. 41.

30. Jacob Chr. Bahne Engel, Sem-Stat S nr. 43.

31. Olde Hinrich Rickmers, Sem-Stat $S$ nr. 35.

32. Johs. Peter Chr. Petersen, Sem-Stat $S$ nr. 40.

33. Peter Jürgen Johannsen, Sem-Stat $S$ nr. 42.

34. uvedkommende sysler, uorden, postyr.

35. Berend Diedrich Wilms, Sem-Stat $S$ nr. 36.

36. Eggert Daniel Büsing, Sem-Stat S nr. 38.

37. Carl Friedrich Richter, Sem-Stat $S$ nr. 39.

38. Adolph Krause, Sem-Stat S nr. 37.

39. Regierungs- u. Schulrat, dr.theol. K.F.Th.Schneider. 
40. Bertel Petersen Godt, se bl.a. Asger Nyholm i Sdj. Arb. 1979, s. $30 \mathrm{ff}$ og 1967 s. $195 \mathrm{ff}$.

41. Andreas Matzen, se O.F.Arends: Gejstligheden i Slesvig og Holsten I, s. 50.

42. Angående branden se Vestslesvigs Tidende.

43. N.A.Tørsleff førte Hagerups danske privatskole i Østergade videre efter sidstnævntes død 1868. Skolen blev forbudt $1872 \mathrm{og}$ Tørsleff rejste til Kongeriget, jfr. note 44.

44. Ang. dyrskuet i Visby og arrestationerne se: Nordslesvigernes Fangenskab i Året 1870 af C.A.Willemoes, genudgivet med indledning og noter af Peter Kr. Iversen, Forlaget Neffen.

45. Gæstgiver Andreas Hansen Blichenberg, nordøstkvarter nr. 81, flytter senere til sydvestkvarteret nr. 188.

46. Matthæus Friedrich Chemnitz, 1815-70.

47. Friedrich Chr. Reinholdt, nordvestkvarter nr. 3.

48. Jens Madsen, dim. 1873, Sem-Stat nr. 1676, Ravn nr. 1877.

49. Købmand Hans Peter Andresen, sydvestkvarter nr. 105-106.

50. Peter Riggelsen, dim. 1877, Sem-Stat nr. 1844, Ravn nr. 2545.

51. Carl Matthias Wilh. Andr. Grünfeld, 1840-83, jfr. Ludw.Andresen: Beiträge zur neueren Geschichte der Stadt Tondern, s. 220.

52. Georg Eduard Altmann Hamrich fik borgerskab som konditor 1855; Han ses ikke død i Tønder.

53. Se note 21 .

54. Disse to foreninger ses iøvrigt ikke at være nævnt $\mathrm{i}$ litteraturen vedrørende seminariet. De danske seminarister synes også en tid at have haft en forening »2. september stiftelse«.

55. Andreas Petersen Svane, dim. 1871, Sem-Stat nr. 1610, Ravn nr. 2820.

56. Peter Christian Lassen, dim. 1874, Sem-Stat nr. 1714, Ravn nr. 1717.

57. Se note 6.

58. Jacob Friedrich Petersen, dim. 1874, Sem-Stat nr. 1720, Ravn nr. 2342.

59. Jens Jessen, dim. 1874, Sem-Stat nr. 1712, Ravn nr. 1389; jfr. iøvrigt s. 61 og 83, note 1 .

60. Mathies Cornelius Mathiesen, dim 1874, Sem-Stat nr. 1717, Ravn nr. 1916.

61. Heinrich Lorenz Iversen, dim. 1872, Sem-Stat nr. 1619. 